DOI: $10.19195 / 0137-1134.111 .13$

\author{
BARBARA ZYZDA
}

Uniwersytet Wrocławski

\title{
KAPITAN STATKU MORSKIEGO JAKO OTOCZENIE ADMINISTRACJI PUBLICZNEJ
}

\begin{abstract}
Abstrakt: Kapitan statku morskiego jest nietypowym podmiotem administrującym, znajdującym się poza strukturą administracji publicznej, lecz wykonującym pewne jej zadania. Kapitan statku jest traktowany jako przedstawiciel władzy poza granicami Rzeczypospolitej Polskiej, dlatego prawodawca przekazał mu kompetencje dotyczące realizacji funkcji administracyjnych państwa, które w zwykłych warunkach zarezerwowane są dla odrębnych podmiotów. W takim zakresie kapitan działa na podstawie norm zawartych w przepisach prawa administracyjnego. Najważniejsze zadania przekazane do realizacji kapitanowi statku wynikają z prawa wyborczego, prawa o aktach stanu cywilnego oraz kodeksu morskiego w zakresie czynności policyjno-śledczych. W niniejszym artykule została przeprowadzona analiza pozycji i funkcji kapitana statku morskiego jako podmiotu stanowiącego element otoczenia administracji publicznej.
\end{abstract}

Słowa kluczowe: podmiot administrujący, kapitan statku morskiego, otoczenie administracji

\section{WSTĘP}

Opisanie pozycji kapitana statku morskiego jako podmiotu stanowiącego element otoczenia administracji publicznej wymaga odwołania się do definicji oraz funkcji administracji publicznej. Zgodnie z ujęciem Jana Bocia ,administracja publiczna jest to przejęte przez państwo i realizowane przez jego zawisłe organy, a także przez organy samorządu terytorialnego zaspokajanie zbiorowych $\mathrm{i}$ indywidualnych potrzeb obywateli, wynikających ze współżycia ludzi w społecznościach"1. Nieco szersze ujęcia prezentują inni przedstawiciele doktryny, w tym Hubert Izdebski i Michał Kulesza, wskazując, że „administrację publiczną rozumie się jako zespół działań, czynności i przedsięwzięć organizatorskich i wykonawczych, prowadzonych na rzecz realizacji interesu publicznego przez różne podmioty, organy i instytucje, na podstawie ustawy i w określonych prawem

\footnotetext{
${ }^{1}$ J. Boć, Pojęcie administracji, [w:] Prawo administracyjne, red. J. Boć, Wrocław 2005, s. 16.
} 
formach" ". Sięgając do starszych opracowań, to administracja była widziana jako planowe zgrupowanie ludzi powołanych w służbie określonej misji publicznej³

Z perspektywy definicji podmiotowej administracja jest organem, co oznacza osobę lub grupę ludzi przynależnych danej organizacji według przyznanej im właściwości ${ }^{4}$. Ujęcie podmiotowe rozszerza pojęcie administracji publicznej o te osoby, które wykonują określone funkcje z zakresu administracji publicznej. Leszek Kaczmarski przedstawia administrację jako swoistą organizację, której członkowie zostali wyposażeni w kompetencje określone w ustawach i w ten sposób realizują funkcje i zadania państwa ${ }^{5}$.

Specyfika administracji publicznej polega na wykorzystywaniu różnorodnych rozwiązań, tak aby w obliczu zmiennych wyzwań i uwarunkowań możliwe było realizowanie jej celu. Co ciekawe, podobne zdanie wyraża judykatura ${ }^{6}$, wskazując, iż przekształcenia $\mathrm{w}$ ramach struktur administracji publicznej są trwałym zjawiskiem ustrojowym, reagującym na rozszerzanie i różnorodność zadań realizowanych przez państwo, czego skutkiem jest zwiększanie liczby podmiotów administrujących, w tym „nietypowych podmiotów administrujących””.

\section{STATUS PRAWNY KAPITANA STATKU}

Właśnie takim nietypowym podmiotem administrującym jest kapitan statku morskiego, którego pozycja $\mathrm{w}$ zakresie wykonywania zadań administracji publicznej jest swego rodzaju fenomenem. Nie może być on charakteryzowany jako organ administracji publicznej, gdyż ,organem administracji publicznej jest człowiek (lub grupa ludzi) znajdujący się w strukturze organizacyjnej państwa lub samorządu terytorialnego, powołany w celu realizacji norm prawa administracyjnego [...] oraz działający w granicach przyznanych mu przez prawo kompetencji”". Widać wyraźnie, że kapitan statku morskiego nie mieści się w zakresie tego pojęcia. Kapitan statku morskiego jest przede wszystkim osobą dowodzącą statkiem, jednakże prawodawca przekazał mu pewne kompetencje dotyczące realizacji funkcji administracyjnych państwa i w tym względzie działa on na podstawie norm prawa administracyjnego. Może być on traktowany jako element otoczenia

${ }^{2}$ H. Izdebski, M. Kulesza, Administracja publiczna. Zagadnienia ogólne, Warszawa 2004, s. 93.

3 J.S. Langrod, Instytucje prawa administracyjnego. Zarys części ogólnej, Kraków 2003, (reprint), s. 228.

${ }^{4}$ W. Jakimowicz, Wyktadnia prawa administracyjnego, Kraków 2006, s. 89.

${ }^{5}$ L. Kaczmarski, Ewolucja pojęcia administracji publicznej w polskiej doktrynie prawa administracyjnego po II wojnie światowej, „PWSZ IPiA Studia Lubuskie” 5, Sulechów 2009, s. 237.

${ }^{6}$ Zob. uchwała składu siedmiu sędziów NSA z dnia 22 lutego 2002 roku, II GPS/06, LEX nr 268925.

${ }^{7}$ P.J. Suwaj, J. Zimmermann, Administracja, [w:] Wpływ przemian cywilizacyjnych na prawo administracyjne i administracje publiczna, red. P.J. Suwaj, J. Zimmermann, Warszawa 2013, s. 27.

8 J. Boć, Organizacja prawna administracji, [w:] Prawo administracyjne, s. 137. 
administracji, a ściślej podmiot administrujący, któremu prawo przydało funkcję administrowania ${ }^{9}$.

Doktryna nie definiuje otoczenia administracji publicznej, jednak odpowiednie wydaje się $\mathrm{w}$ tym miejscu skorzystanie $\mathrm{z}$ rozwiązań wypracowanych przez przedstawicieli nauki organizacji i zarządzania i ich analogiczne zastosowanie. James A.F. Stoner, opisując otoczenie organizacji, zalicza do niego „wszystkie elementy znajdujące się poza organizacją, mające związek z jej funkcjonowaniem, w tym elementy o bezpośrednim i pośrednim oddziaływaniu" 10 . W otoczeniu organizacji wyróżnia się otoczenie zewnętrzne (dalsze), składające się z otoczenia ogólnego - bliżej niesprecyzowanego, lecz wywierającego szeroki wpływ na organizację wymiaru ekonomicznego, technicznego, socjokulturowego, prawno-politycznego i międzynarodowego oraz otoczenia celowego - obejmującego konkretne elementy oddziałujące na organizację. Otoczeniem wewnętrznym organizacji są z kolei wszystkie elementy wchodzące w skład jej struktury ${ }^{11}$.

Przekładając dorobek nauki organizacji i zarządzania na grunt nauki administracji, można dojść do wniosku, że otoczenie administracji publicznej to otoczenie ogólne (dalsze), na które składają się warunki funkcjonowania administracji oraz otoczenie szczegółowe (bliższe), tworzone przez wszystkie organizacje i podmioty wchodzące $\mathrm{z}$ administracją publiczną we wzajemne zależności ${ }^{12}$. Zasadne jest więc stwierdzenie, iż kapitan jest podmiotem funkcjonującym w sferze otoczenia administracji publicznej, a ściślej należy on do otoczenia bliższego.

Ustawodawca przyznał kapitanowi statku wiele funkcji, które w normalnych warunkach (na lądzie) zarezerwowane są dla odrębnych podmiotów. Jest to konsekwencja traktowania kapitana statku jako przedstawiciela władzy poza granicami Rzeczypospolitej Polskiej ${ }^{13}$. W obrębie tych funkcji znajdują się funkcje kapitana statku morskiego dotyczące możliwości sporządzenia testamentu podróżnego czy zatrzymania osoby podejrzanej o popełnienie przestępstwa na polskim statku morskim, ale także funkcje, których źródłem są normy prawa administracyjnego, w tym prawa wyborczego i prawa o aktach stanu cywilnego, i to one będą przedmiotem analizy w niniejszym opracowaniu.

Opisanie wskazanych funkcji realizowanych przez kapitana statku morskiego wymaga kilku słów wprowadzenia i wyjaśnienia, kim jest kapitan statku morskiego. Ustawodawca nie zawarł definicji legalnej kapitana w kodeksie morskim ${ }^{14}$, mając jednak na uwadze zakres obowiązków kapitana statku morskiego oraz ważność sta-

\footnotetext{
9 Ibidem, s. 139.

10 J.A.F. Stoner, R. Freeman, D.R. Gilbert jr, Kierowanie, Warszawa 2001, s. 79.

${ }^{11}$ R. Griffin, Podstawy zarzadzania organizacjami, Warszawa 1998, s. 129.

12 A. Chrisidu-Budnik, Organizacja i jej otoczenie, [w:] A. Chrisidu-Budnik et al., Nauka organizacji i zarzadzania, Wrocław 2005, s. 193.

${ }^{13}$ M.H. Koziński, Kapitan statku, [w:] Prawo morskie, t. 3, red. J. Łopuski, Bydgoszcz 1998,

14 Ustawa z dnia 18 września 2001 roku - Kodeks morski (Dz.U. z 2016 r. poz. 66).
} s. 215. 
nowiska, należy przyjąć, że kapitan statku to wyznaczona przez armatora osoba, która na podstawie stosunku pracy sprawuje zwierzchnictwo nad statkiem morskim, ma wiedzę i kwalifikacje zawodowe udokumentowane przez właściwe organy państwowe, niezbędne doświadczenie, a także znajomość zasad dobrej praktyki morskiej ${ }^{15}$.

W kodeksie morskim nie wskazano kwalifikacji, które powinien mieć kapitan. Co prawda są one wymienione w konwencji STCW ${ }^{16}$ oraz w rozporządzeniu określającym wyszkolenie i kwalifikacje członków załóg statków morskich ${ }^{17}$, ale w żadnym z dokumentów nie znalazł się przepis odnoszący się do kwalifikacji kapitana w kontekście sprawowania zastępstwa za niektóre organy państwowe.

Ze względu na szeroki zakres funkcji przypisanych jednej osobie pozycja kapitana statku morskiego jest szczególnym rodzajem zwierzchnictwa występującego w działalności gospodarczej, cechującym się zwiększonym zakresem odpowiedzialności i ryzyka. Długotrwałe oddalenie statku od normalnych warunków życia społecznego, w tym instytucji i organizacji, powoduje, że kapitan często nie może polegać na bezpośredniej pomocy w podejmowanych działaniach. Należy pamiętać, że kapitan wykonuje czynności w różnych warunkach politycznych, ekonomicznych, organizacyjnych i prawnych ${ }^{18}$.

\section{FUNKCJE KAPITANA JAKO PODMIOTU ADMINISTRUJĄCEGO}

Przechodząc do poszczególnych funkcji sprawowanych przez kapitana przede wszystkim kapitan statku morskiego ma kompetencje wynikające z przepisów Prawa o aktach stanu cywilnego ${ }^{19}$, w którego rozdziale siódmym uregulowany został szczególny tryb rejestracji stanu cywilnego. Na mocy art. 96 p.a.s.c. urodzenie lub zgon na polskim statku morskim niosą doniosłe konsekwencje wobec kapitana, który jest zobowiązany do sporządzenia protokołu potwierdzającego urodzenie lub zgon na statku ${ }^{20}$. W normalnych warunkach informacje te zawierane

${ }^{15}$ Zob. B. Zyzda, Publicznoprawne funkcje kapitana statku morskiego, [w:] Z badań nad prawem, administracją i myśla polityczna, ,Acta Erasmiana” 10, Wrocław 2015, s. 183-184.

16 Międzynarodowa konwencja o wymaganiach w zakresie wyszkolenia marynarzy, wydawania im świadectw oraz pełnienia wacht z 7 lipca 1978 r. (International Convention on Standards of Training, Certification and Watchkeeping for Seafarers).

${ }^{17}$ Rozporządzenie Ministra Transportu, Budownictwa i Gospodarki Morskiej z dnia 7 sierpnia 2013 roku w sprawie wyszkolenia i kwalifikacji członków załóg statków morskich (Dz.U. z 2017 r. poz. 167).

${ }^{18}$ Leksykon prawa morskiego - 100 podstawowych pojęć, red. D. Pyć, J. Zużewicz-Wiewiórska, Warszawa 2013, s. 214.

${ }^{19}$ Ustawa z dnia 28 listopada 2014 roku — Prawo o aktach stanu cywilnego (Dz.U. z 2016 r. poz. 2064, dalej: p.a.s.c.).

${ }^{20}$ Protokół potwierdzający urodzenie zawiera między innymi: nazwiska, nazwiska rodowe, imiona, daty urodzenia i numery PESEL rodziców, podpis matki, datę i godzinę urodzenia dziecka według miejsca zdarzenia oraz informację, czy dziecko urodziło się żywe, czy martwe, jego płeć, 
są w karcie urodzenia lub karcie zgonu, wydawanej odpowiednio przez personel szpitala, w którym odbył się poród, lub przez lekarza stwierdzającego zgon. Protokół urodzenia lub zgonu, w zależności od miejsca zdarzenia - w kraju lub za granicą, kapitan statku przekazuje kierownikowi urzędu stanu cywilnego pierwszego polskiego portu, do którego zawinął statek, lub konsulowi ${ }^{21}$.

Należy tu przytoczyć art. 16 ustawy o cmentarzach i chowaniu zmarłych ${ }^{22}$, w myśl którego ciała osób zmarłych na statkach będących na pełnym morzu należy zgodnie ze zwyczajem morskim pochować przez zatopienie w morzu ${ }^{23}$. Jeśli jednak statek może w ciągu 24 godzin przybyć do objętego programem podróży portu, to zwłoki należy dowieźć na ląd i tam pochować. Wyjątki od tej zasady mogą być czynione jedynie przez kapitana statku, przy uwzględnieniu wskazań sanitarnych ${ }^{24}$. Obecnie zwyczaj ten, ze względu na rozwój techniki i skrócenie czasu rejsów, ma marginalne zastosowanie.

Kolejna z funkcji kapitana statku morskiego wynika z przepisów prawa wyborczego ${ }^{25}$. Przewidują one sytuację, gdy dzień wyborów do Sejmu i Senatu, wyborów prezydenta Rzeczypospolitej lub wyborów do Parlamentu Europejskiego w Rzeczypospolitej Polskiej przypada w okresie podróży polskim statkiem. Zgodnie $\mathrm{z}$ art. 15 kodeksu wyborczego na statku tworzony jest odrębny obwód głosowania, jeśli zostaną spełnione dodatkowe warunki: na statku musi przebywać minimum piętnastu wyborców uprawnionych do głosowania oraz musi istnieć możliwość niezwłocznego przekazania do właściwej komisji wyborczej wyników głosowania ${ }^{26}$. W myśl art. $34 \S 3 \mathrm{w}$ zw. z art. 32 § 1 kodeksu wyborczego kapitan statku morskiego na pisemny wniosek wyborcy zmieniającego miejsce pobytu przed dniem wyborów wydaje zaświadczenie o prawie do głosowania w miejscu pobytu w dniu wyborów. Do obowiązków kapitana, zgodnie z art. $16 \S 4$ kodeksu wyborczego, należy niezwłoczne zawiadomienie wyborców o utworzeniu obwodu głosowania na polskim statku, a także wpisanie wyborców przebywających na

imiona i nazwiska świadków potwierdzających zdarzenie oraz ich podpisy, a także imię i nazwisko kapitana statku.

${ }^{21}$ A. Czajkowska, Komentarz do art. 97, [w:] Prawo o aktach stanu cywilnego z komentarzem. Przepisy wykonawcze i związowe oraz wzory dokumentów, red. A. Czajkowska, Warszawa 2015, s. 214.

22 Ustawa z dnia 31 stycznia 1959 roku o cmentarzach i chowaniu zmarłych (Dz.U. z 2017 r. poz. 912).

${ }^{23}$ P. Radwański, Publiczno-prawne kompetencje kapitana, „Nasze Morze” 2008, nr 9, s. 48.

${ }^{24}$ E. Darmorost, Ustawa o cmentarzach i chowaniu zmartych. Komentarz, Warszawa 2014, s. 78.

${ }^{25}$ Ustawa z dnia 5 stycznia 2011 roku — Kodeks wyborczy (Dz.U. z 2017 r. poz. 15).

${ }^{26}$ Obwody są tworzone na niektórych statkach na podstawie rozporządzeń wydanych na podstawie art. $15 \S 3$ kodeksu wyborczego każdorazowo dla zarządzonych wyborów. Zob. rozporządzenie Ministra Infrastruktury i Rozwoju z dnia 16 października 2015 roku w sprawie utworzenia obwodów głosowania na polskich statkach morskich w wyborach do Sejmu Rzeczypospolitej Polskiej i do Senatu Rzeczypospolitej Polskiej (Dz.U. poz. 1650), rozporządzenie Ministra Infrastruktury i Rozwoju z dnia 24 kwietnia 2015 roku w sprawie utworzenia obwodów głosowania na polskich statkach morskich w wyborach Prezydenta Rzeczypospolitej Polskiej (Dz.U. poz. 590). 
polskim statku morskim znajdującym się w podróży w dniu wyborów na listę wyborców. Wpisu na listę wyborców kapitan dokonuje na pisemny wniosek wyborcy zgłoszony najpóźniej w trzecim dniu przed dniem wyborów ${ }^{27}$.

Również przepisy referendalne $\mathrm{w}$ odniesieniu do referendum ogólnokrajowego przewidują tworzenie obwodów do głosowania dla obywateli polskich przebywających na statkach morskich z odpowiednim zastosowaniem przepisów kodeksu wyborczego ${ }^{28}$. Kapitan statku zgodnie z art. 14 ust. 1 ustawy zgodnie z przepisami wykonawczymi po utworzeniu obwodu w formie pisemnej decyzji powołuje komisję obwodową do przeprowadzenia czynności referendalnych ${ }^{29}$. Do uczestniczenia w referendum dopuszczone są osoby uprawnione do udziału przebywające na statku, ujęte w spisie sporządzonym przez kapitana ${ }^{30}$.

$\mathrm{Na}$ kapitanie statku spoczywa obowiązek zapewnienia porządku i prawidłowego przebiegu głosowania, zarówno w wyborach, jak i w referendum ogólnokrajowym, w szczególności utrzymanie ciągłości głosowania, przerwanie, przedłużenie lub odroczenie do dnia następnego głosowania w razie zaistnienia nadzwyczajnych okoliczności, przejściowo uniemożliwiających jego prawidłowy przebieg. W tym zakresie uprawnienia kapitana statku regulują odpowiednie akty wykonawcze ${ }^{31}$. Zgodnie z nimi kapitan wyznacza jedno pomieszczenie na statku, które pełni funkcję lokalu obwodowej komisji wyborczej lub do spraw referendum, oraz zapewnia zamknięcie tego lokalu w czasie przerwy w głosowaniu w sposób uniemożliwiający dostanie się osób nieupoważnionych. Jest on także obecny przy zamykaniu lokalu komisji obwodowej po pierwszym dniu wyborów i opieczętowuje wejście do tego lokalu pieczęcią komisji, przechowuje klucze do

27 Zob. rozporządzenie Ministra Gospodarki Morskiej i Żeglugi Śródlądowej z dnia 31 marca 2017 roku w sprawie spisu wyborców dla obwodów głosowania utworzonych na polskich statkach morskich (Dz.U. poz. 829), a także K.W. Czaplicki et al., Kodeks wyborczy. Komentarz, Warszawa 2014, s. 101.

${ }^{28}$ Zob. art. 6 ust. 1 pkt 5 i ust. 3 ustawy z dnia 14 marca 2003 roku o referendum ogólnokrajowym (Dz.U. z 2015 r. poz. 318 z późn. zm.).

${ }^{29}$ Zob. § 3 i 9 uchwały Państwowej Komisji Wyborczej z dnia 6 lipca 2015 roku w sprawie trybu i terminu powoływania obwodowych komisji do spraw referendum w obwodach głosowania utworzonych na polskich statkach morskich w referendum ogólnokrajowym (M.P. poz. 632).

30 Zob. rozporządzenie Ministra Infrastruktury z dnia 30 kwietnia 2003 roku w sprawie sposobu sporządzania i aktualizacji spisu osób uprawnionych do udziału w referendum ogólnokrajowym dla obwodów głosowania utworzonych na polskich statkach morskich (Dz.U. Nr 74, poz. 669).

${ }^{31}$ Rozporządzenie Ministra Infrastruktury i Rozwoju z dnia 21 kwietnia 2015 roku w sprawie szczegółowych wymagań oraz obowiązków kapitana polskiego statku morskiego w zakresie ochrony lokalu obwodowej komisji wyborczej w czasie przerwy w głosowaniu spowodowanej nadzwyczajnymi wydarzeniami (Dz.U. poz. 576); rozporządzenie Ministra Infrastruktury z dnia 1 października 2010 roku w sprawie szczegółowych wymagań oraz obowiązków kapitana polskiego statku morskiego w zakresie ochrony lokalu obwodowej komisji wyborczej w czasie przerwy w głosowaniu w wyborach do Parlamentu Europejskiego (Dz.U. Nr 189, poz. 1267); rozporządzenie Ministra Infrastruktury z dnia 30 kwietnia 2003 roku w sprawie szczegółowych wymagań oraz obowiązków kapitana polskiego statku morskiego w zakresie ochrony lokalu obwodowej komisji do spraw referendum w czasie przerwy w głosowaniu (Dz.U. Nr 75, poz. 675). 
lokalu komisji obwodowej w kasie pancernej statku, wyznacza członka załogi, który jest odpowiedzialny za stałą ochronę lokalu komisji obwodowej, a także jest obecny drugiego dnia podczas sprawdzania przez przewodniczącego komisji obwodowej, czy pieczęcie na wejściu do lokalu nie zostały naruszone.

Kapitan statku pełni też funkcję organu przyjmującego i rozpatrującego odwołania dotyczące utworzonego przez niego spisu wyborców. W odniesieniu do wyborów do Sejmu oraz wyborów Prezydenta Rzeczypospolitej protest wyborczy może być skutecznie wniesiony w ciągu siedmiu dni od dnia ogłoszenia wyników wyborów, jeśli zostanie złożony odpowiedniemu kapitanowi statku ${ }^{32}$. Kapitan pełni więc funkcje zwykle wykonywane przez Krajowe Biuro Wyborcze lub organy administracji samorządu terytorialnego ${ }^{33}$.

Istotne uprawnienia przysługują kapitanowi statku w zakresie określenia zasad i warunków sprzedaży, podawania i spożywania napojów alkoholowych na morskich statkach handlowych $w$ żegludze międzynarodowej ${ }^{34}$. Zgodnie z nim dopuszcza się sprzedaż, podawanie i spożywanie napojów alkoholowych w odniesieniu do pasażerów, którzy odbywają podróż na statku oraz kapitana statku na cele reprezentacyjne. Kapitan ma uprawnienie do wydania zezwolenia na sprzedaż napojów alkoholowych z przeznaczeniem do spożycia poza statkiem dla pasażerów statku w przeddzień wyokrętowania, przedstawicieli władz w portach zagranicznych i agentów zagranicznych polskich armatorów. Ponadto kapitan może zezwolić na wydawanie i spożywanie w nieznacznych ilościach alkoholu i napojów alkoholowych zawierających powyżej 4,5\% alkoholu dla członków załogi w dniach jubileuszów i uroczystości wynikających ze zwyczajów morskich w czasie wolnym od służby oraz dla uczestników przyjęć dla delegacji zagranicznych organizowanych na statku. Nieznaczna ilość jest tu rozumiana jako 0,1 litra napoju zawierającego powyżej 18\% alkoholu lub 0,2 litra napoju o zawartości alkoholu od 4,5\% do $18 \%$. Rozporządzenie zastrzega jednak, że przez wzgląd na

32 Zob. art. $241 \S 2$ kodeksu wyborczego odnośnie do wyborów parlamentarnych do Parlamentu Europejskiego i art. $321 \S 2$ kodeksu odnośnie do wyborów prezydenta, a także art. 34 ust. 2 ustawy o referendum ogólnokrajowym, który odsyła do odpowiedniego stosowania przepisów kodeksu wyborczego, co potwierdza tym samym właściwość kapitana statku do przyjmowania protestów i przekazywania ich do sądów z zachowaniem terminu złożenia protestu. Zob. też Kodeks morski. Komentarz, red. D. Pyć, I. Zużewicz-Wiewiórowska, LEX/el. 2012, s. 96.

${ }^{33}$ Zgodnie $\mathrm{z}$ art. 12 kodeksu wyborczego obwody głosowania tworzone są na obszarach gmin przez rady gmin w drodze uchwały na wniosek wójta, a w myśl art. $18 \S 11$ rejestr wyborców prowadzony jest przez gminy jako zadanie zlecone, $\mathrm{z}$ kolei zgodnie $\mathrm{z}$ art. 13 ustawy o referendum ogólnokrajowym komisje obwodowe powołuje wójt lub burmistrz (prezydent miasta).

${ }^{34} \mathrm{Na}$ podstawie rozporządzenia Ministra-Kierownika Urzędu Gospodarki Morskiej z dnia 7 maja 1983 roku w sprawie zasad i warunków sprzedaży, podawania i spożywania napojów alkoholowych na morskich statkach handlowych w żegludze międzynarodowej oraz w międzynarodowych portach morskich (Dz.U. Nr 25, poz. 121) wydanego na podstawie delegacji z art. 14 ust. 7 ustawy z dnia 26 października 1982 roku o wychowaniu w trzeźwości i przeciwdziałaniu alkoholizmowi (Dz.U. z 2016 r. poz. 487). 
bezpieczeństwo i porządek na statku kapitan statku może wprowadzić częściowy lub całkowity zakaz sprzedaży, podawania i spożywania napojów alkoholowych.

Kolejną z funkcji kapitana statku morskiego mieszczącą się w obszarze funkcji publicznych jest działalność kapitana w zakresie czynności policyjno-śledczych. Kodeks morski w art. 72, w razie popełnienia na statku przestępstwa, nakłada na kapitana obowiązek sporządzenia szczegółowego zawiadomienia o popełnieniu przestępstwa. Ponadto kapitan statku musi przedsięwziąć odpowiednie środki mające na celu zapobieżenie uchyleniu się osoby podejrzanej o popełnienie przestępstwa od poniesienia odpowiedzialności karnej i zabezpieczyć dowody ${ }^{35}$. Kapitan może zastosować zatrzymanie takiej osoby w odosobnionym pomieszczeniu ${ }^{36}$. O popełnieniu przestępstwa na statku lub zatrzymaniu osoby podejrzanej o popełnienie przestępstwa kapitan, za pośrednictwem dyrektora urzędu morskiego, informuje prokuratora właściwego ze względu na port macierzysty statku ${ }^{37}$. Następnie, stosownie do okoliczności, osoba podejrzana o popełnienie przestępstwa powinna zostać przekazana wraz z zawiadomieniem o przestępstwie do właściwego organu w pierwszym polskim porcie, do którego statek zawinął. Jeśli zaś do zdarzenia doszło na statku niezmierzającym do polskiego portu, kapitan statku powinien przekazać osobę podejrzaną o popełnienie przestępstwa, razem z dowodami, kapitanowi innego polskiego statku płynącego do portu polskiego lub jednostce pływającej Policji, Straży Granicznej lub Marynarki Wojennej. W przypadku zatrzymania osoby podejrzanej o popełnienie przestępstwa, niemającej polskiego obywatelstwa, kapitan ma obowiązek za pośrednictwem dyrektora urzędu morskiego zawiadomić także Ministra Sprawiedliwości. Takiej osobie kapitan statku, w ramach posiadanych środków technicznych, powinien umożliwić skontaktowanie się z przedstawicielami państwa, którego jest obywatelem, lub, jeśli nie ma obywatelstwa, z przedstawicielami państwa, w którym dana osoba ma stałe miejsce zamieszkania. Kapitan powinien umożliwić wizytę na statku przedstawiciela tego państwa ${ }^{38}$.

Podobnie jak w wypadku wydawania zezwoleń na sprzedaż, podawanie i spożywanie alkoholu na statku, gdy kapitan występuje w funkcji organu administracji, tak i w wypadku procedur cywilnych i administracyjnych zastępuje on organy władzy publicznej. Zarówno kodeks postępowania cywilnego ${ }^{39}$, kodeks postępowania administracyjnego ${ }^{40}$, jak i Prawo o postępowaniu przed sądami ad-

${ }^{35}$ Kodeks morski, s. 68.

${ }^{36}$ P. Radwański, Publicznoprawne kompetencje kapitana, „Nasze Morze” 2009, nr 1, s. 54.

37 Zob. § 2 rozporządzenia Ministra Infrastruktury z dnia 23 lutego 2005 roku w sprawie trybu postępowania kapitana statku wobec osoby podejrzanej o popełnienie przestępstwa przeciwko bezpieczeństwu żeglugi morskiej (Dz.U. Nr 42, poz. 405).

38 G. Sidor, Zatrzymanie osoby przez kapitana statku morskiego, „Studia Iuridica Lublinensia” 2014, nr 21, s. 220.

${ }^{39}$ Ustawa z dnia 17 listopada 1974 roku — Kodeks postępowania cywilnego (Dz.U. z 2016 r. poz. 1822 z późn. zm.).

${ }^{40}$ Ustawa z dnia 14 czerwca 1960 roku — Kodeks postępowania administracyjnego (Dz.U. z 2016 r. poz. 23 z późn. zm.). 
ministracyjnymi ${ }^{41}$ wskazują, że termin jest zachowany, jeżeli przed jego upływem pismo zostanie złożone przez członka załogi polskiego statku morskiego u kapitana statku.

Kolejną z funkcji kapitana statku jest zapewnienie bezpieczeństwa statku oraz osób i towarów znajdujących się na nim. W związku z tym ustawodawca przewiduje obowiązek, zgodnie z którym wszystkie osoby przebywające na statku muszą się podporządkować zarządzeniom kapitana wydanym w celu zapewnienia bezpieczeństwa i porządku statku. Kapitan jest upoważniony do użycia wszelkich racjonalnych środków mających na celu uchronienie statku, osób przebywających na statku i ładunku przed szkodą ${ }^{42}$.

Na kapitanie spoczywają także zadania organów administracji publicznej w zakresie zapobiegania oraz zwalczania zakażeń i chorób zakaźnych u ludzi w postaci obowiązku zgłoszenia rozpoznania lub powzięcia podejrzenia zakażenia chorób zakaźnych ${ }^{43}$. Jeśli w czasie podróży międzynarodowej zaistnieje podejrzenie, że pasażer lub członek załogi statku zachorował na szczególnie niebezpieczną i wysoce zakaźną chorobę lub jeśli dojdzie do zgonu z powodu takiej choroby, kapitan statku morskiego osobiście lub za pośrednictwem Morskiej Służby Poszukiwania i Ratownictwa, kapitanatu portu albo agenta statku jest zobowiązany do niezwłocznego zgłoszenia takiej sytuacji za pomocą dostępnych środków łączności do państwowego powiatowego inspektora sanitarnego lub do państwowego granicznego inspektora sanitarnego właściwego dla planowanego miejsca przekroczenia granicy państwowej albo portu morskiego.

$\mathrm{W}$ art. 65 kodeksu morskiego wskazany jest obowiązek kapitana do okazywania bandery statku jednostkom pływającym Straży Granicznej i Marynarki Wojennej oraz do podnoszenia bandery podczas wpływania statku do portu. Szczegółowy tryb realizacji tej powinności uregulowany jest w rozporządzeniu wykonawczym ${ }^{44}$. Zgodnie z jego postanowieniami kapitan statku o polskiej przynależności od wschodu do zachodu słońca okazuje banderę wymienionym jednostkom, przechodząc $w$ ich pobliżu lub na ich żądanie. Bandera powinna być okazana na flagsztoku rufowym statku, a jeśli nie jest to możliwe, to w innym widocznym miejscu.

${ }^{41}$ Ustawa z dnia 30 sierpnia 2000 roku — Prawo o postępowaniu przed sądami administracyjnymi (Dz.U. z 2016 r. poz. 718 z późn. zm.).

42 Stanowi o tym art. $61 \S 1$ i art. $68 \S 1$ kodeksu morskiego. Zob. też M. Kijowski, Kapitan statku morskiego jako fenomen prawny, [w:] Hierarchia i dialog, red. P. Szreniawski, Lublin 2017, s. 98.

${ }^{43}$ Stanowi o tym art. 27 ust. 8 pkt 2 ustawy z dnia 5 grudnia 2008 roku o zapobieganiu oraz zwalczaniu zakażeń i chorób zakaźnych u ludzi (Dz.U. z 2016 r. poz. 1866 z późn. zm.).

${ }^{44}$ Rozporządzenie Ministra Infrastruktury z dnia 8 marca 2004 roku w sprawie sposobu i warunków okazywania bandery statku jednostkom pływającym Marynarki Wojennej i Straży Granicznej oraz oddawania honoru przez statki (Dz.U. Nr 46, poz. 441). 


\section{ZAKOŃCZENIE}

Przeprowadzona analiza wybranych aktów prawa dowodzi, że polski prawodawca potraktował kapitana statku morskiego w sposób wyjątkowy i przekazał mu liczne funkcje wykonywane w normalnych warunkach przez inne kwalifikowane podmioty. Wyjątkowość jego pozycji wiąże się także z tym, iż znajduje się on poza systemem podmiotów administrujących, do którego przedstawiciele doktryny zaliczają podmioty administrujące samorządu terytorialnego, administracji rządowej, zarówno centralnej, jak i terytorialnej, administracji regulacyjnej oraz administracji Unii Europejskiej. W literaturze wyodrębnia się także kategorię innych podmiotów administrujących, jednak kapitan statku morskiego nie jest ujmowany także w tej klasyfikacji ${ }^{45}$.

W wielu przypadkach obowiązki kapitana dotyczą sfery informacyjnej oraz organizacyjnej. Kapitan, oprócz rzetelnej wiedzy stwierdzonej odpowiednimi dokumentami i odbytej praktyki morskiej, powinien cechować się najwyższymi standardami moralnymi, tak aby nie wykorzystywać przydanych funkcji niezgodnie z ich celem. Kapitan statku morskiego oczywiście nie może być traktowany jako organ administracji publicznej, ale niniejsze rozważania dowodzą, że jego funkcja w otoczeniu administracji publicznej stanowi fenomen.

\section{ADMINISTERING ENTITIES IN THE EXAMPLE OF MASTER OF THE SEA SHIP}

\section{Summary}

The master of the sea ship is the untypical administering entity whose position in the scope of public administration tasks is a kind of phenomenon. The ship captain is treated as the representative of government beyond the boarders of the Republic of Poland. The legislator gave him certain competences concerning the realization of national administrative functions which are usually reserved for a few entities in the normal conditions. In such scope, the captain works on the basis of administrative law norms. The most important tasks of captain result from the franchise, Act on Registry Office Records and Maritime Code in the range of police investigation. This article presents the analysis of sea ship captain functions as the entity constituting the element of public administration environment. istration

Keywords: public administration environment, master of the sea ship, captain, public admin-

${ }^{45}$ M. Stahl, Zagadnienia ogólne, [w:] System prawa administracyjnego, red. R. Hauser, Z. Niewiadomski, A. Wróbel, t. 6. Podmioty administrujące, Warszawa 2011, s. 12. 


\section{BIBLIOGRAFIA}

Boć J., Organizacja prawna administracji, [w:] Prawo administracyjne, red. J. Boć Wrocław 2005. Boć J., Pojęcie administracji, [w:] Prawo administracyjne, red. J. Boć Wrocław 2005.

Chrisidu-Budnik A., Organizacja i jej otoczenie, [w:] A. Chrisidu-Budnik, J. Korczak, A. Pakuła, J. Supernat, Nauka organizacji i zarzadzania, Wrocław 2005.

Czajkowska A., Komentarz do art. 97, [w:] Prawo o aktach stanu cywilnego z komentarzem. Przepisy wykonawcze i zwiazkowe oraz wzory dokumentów, red. A. Czajkowska,Warszawa 2015.

Czaplicki K.W., Dauter B., Jaworski S.J., Kisielewicz A., Rymarz F., Kodeks wyborczy. Komentarz, Warszawa 2014.

Darmorost E., Ustawa o cmentarzach i chowaniu zmartych. Komentarz, Warszawa 2014.

Griffin R.W., Podstawy zarzadzania organizacjami, Warszawa 1998.

Izdebski H., Kulesza M., Administracja publiczna. Zagadnienia ogólne, Warszawa 2004.

Jakimowicz W., Wykładnia prawa administracyjnego, Kraków 2006.

Kaczmarski L., Ewolucja pojęcia administracji publicznej w polskiej doktrynie prawa administracyjnego po II wojnie światowej, „PWSZ IPiA Studia Lubuskie” 5, Sulechów 2009.

Kijowski M., Kapitan statku morskiego jako fenomen prawny, [w:] Hierarchia i dialog, red. P. Szreniawski, Lublin 2017.

Kodeks morski. Komentarz, red. D. Pyć, I. Zużewicz-Wiewiórowska, LEX/el. 2012.

Koziński M.H., Kapitan statku, [w:] Prawo morskie, t. 3, red. J. Łopuski, Bydgoszcz 1998.

Langrod J.S., Instytucje prawa administracyjnego. Zarys części ogólnej, Kraków 2003, (reprint).

Leksykon prawa morskiego - 100 podstawowych pojęć, red. D. Pyć, I. Zużewicz-Wiewiórowska, Warszawa 2013.

Radwański P., Publiczno-prawne kompetencje kapitana, „Nasze Morze” 2008, nr 9.

Radwański P., Publicznoprawne kompetencje kapitana, „Nasze Morze” 2009, nr 1.

Sidor G., Zatrzymanie osoby przez kapitana statku morskiego, „Studia Iuridica Lublinensia” 2014, nr 21.

Stahl M., Zagadnienia ogólne, [w:] System Prawa Administracyjnego, red. R. Hauser, Z. Niewiadomski, A. Wróbel, t. 6. Podmioty administrujące, Warszawa 2011.

Stoner J.A.F., Freeman R., Gilbert D., Kierowanie, Warszawa 2001.

Suwaj P.J., Zimmermann J., Administracja, [w:] Wplyw przemian cywilizacyjnych na prawo administracyjne i administracje publiczna, red. P.J. Suwaj, J. Zimmermann, Warszawa 2013.

Zyzda B., Publicznoprawne funkcje kapitana statku morskiego, [w:] Z badań nad prawem, administracją i myśla polityczną, „Acta Erasmiana” 10, Wrocław 2015. 